\title{
New Dipinti in the Birth Portico of the Hatshepsut Temple at Deir el-Bahari
}

\author{
MirosŁaW BARWIK
}

\begin{abstract}
The subject of the present paper are two hitherto unpublished hieratic dipinti from the Birth Portico of the Temple of Queen Hatshepsut at Deir el-Bahari. One of them had been written on the north wall of the portico and can be related precisely to the second phase of restoration undertaken in the Temple of Queen Hatshepsut in the post-Amarna period, and more specifically to the reign of Ramesses II. The other inscription, written on the south wall of the portico, can be ascribed to a certain Minnakht and his colleague Ired, presumably builders of the temple. In addition, a comment on other dipinti on the walls of the portico and its pillars has been included.
\end{abstract}

Keywords: New Kingdom Egypt, hieratic dipinti, Deir el-Bahari, Hatshepsut temple, ancient restorations

Mirosław Barwik, Institute of Archaeology, University of Warsaw, Warszawa; mbarwik@uw.edu.pl

Several dipinti painted on the pillars of the Birth Portico in the Temple of Queen Hatshepsut at Deir el-Bahari have been interpreted as testimony of the functioning of a restorers' atelier in this particular place. ${ }^{1}$ These are mostly figural sketches and some hieratic dockets. ${ }^{2}$ As a matter of fact, something like instructions for ancient restorers had been left on the north wall of the portico, just beside some restored iconographic motifs and inscriptions. ${ }^{3}$ Sketches of this kind have not been noticed in other parts of the temple except the adjoining hypostyle of the Lower Anubis Shrine (unpublished), and in the Chapel of Hathor built by Thutmose III. ${ }^{4}$

It remains doubtful whether any of the hieratic graffiti on the walls of the portico could be related to a hypothetical atelier used by embalmers preparing the burials of the priests

\footnotetext{
1 Niwiński 1985: 211, 213-227.

${ }^{2}$ Unfortunately, no transcriptions or translations of hieratic graffiti were given in the above-mentioned publication. Interestingly enough, some dates are written there, so it seems that the progress of restoration work was recorded by these dipinti.

3 Martinez 2007; Ćwiek, Sankiewicz 2008.

${ }^{4}$ Cf. Strauß-Seeber 2009; for parallels, see also Epigraphic Survey 2009: 64-67, Pls 96-98.
} 


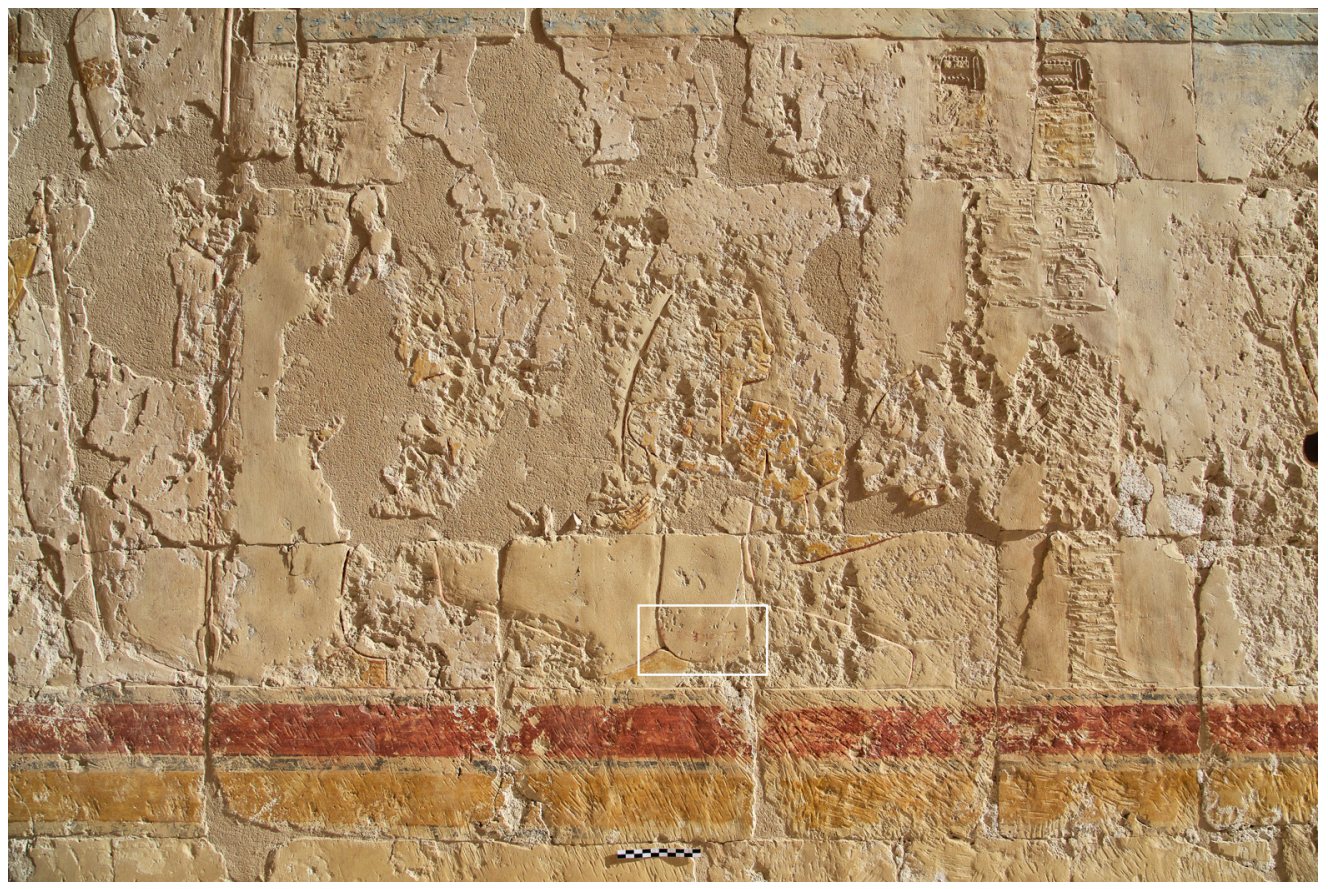

1. Location of the restoration inscription in the frame of the decoration of the Birth Portico, northern wall (Phot. M. Jawornicki).

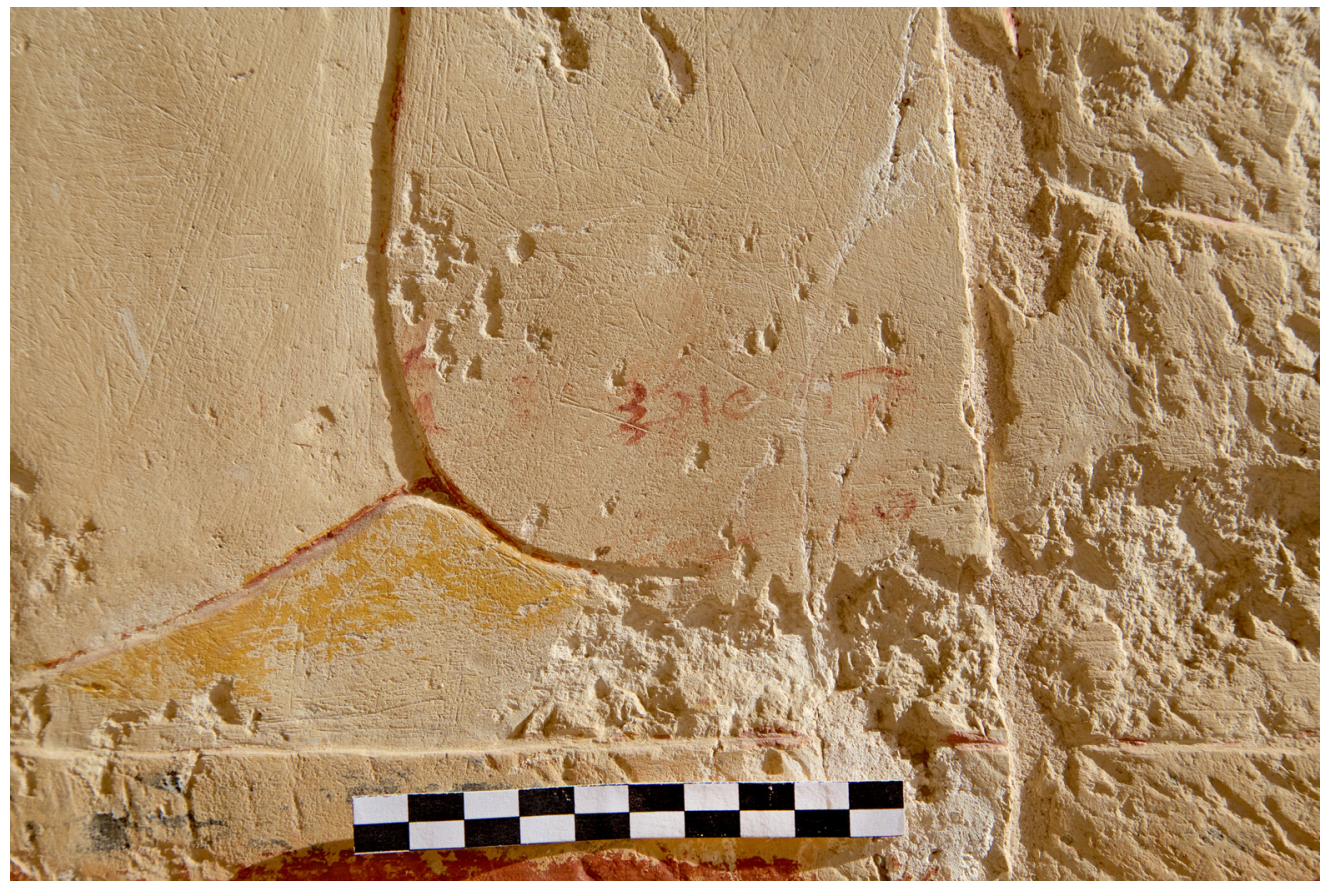

2. Restoration inscription in the Birth Portico, northern wall (Phot. M. Jawornicki). 

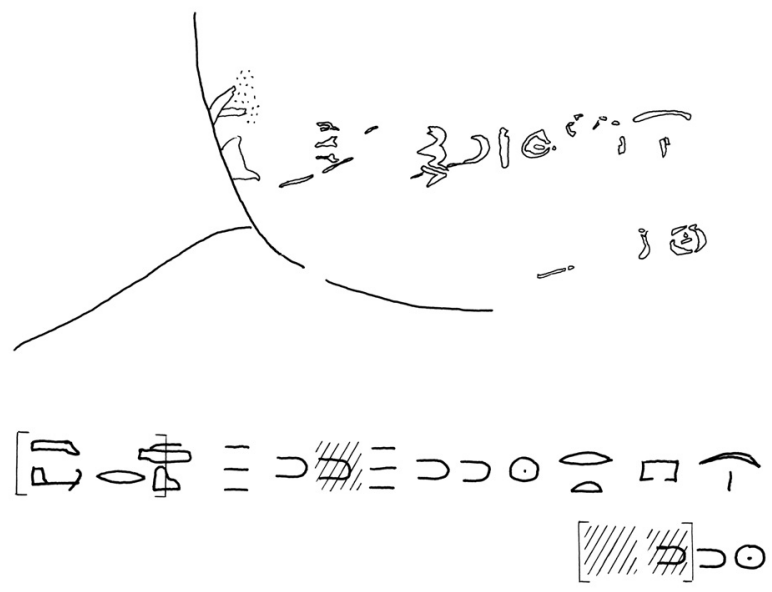

3. Restoration inscription - facsimile and transcription of the text (Drawing: M. Barwik).

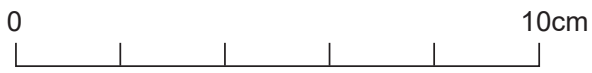

of Amun and Montu during the Third Intermediate Period, which had been located in the temple area, presumably in the northern colonnade of the middle terrace. ${ }^{5}$

Most of the dipinti mentioned above can be interpreted in fact as relating directly to the work of restoration conducted in this part of the temple in the early Nineteenth Dynasty. Restoration inscriptions in the name of Ramesses II, left in many places on the walls of the portico, provide a chronological point of reference for these actions. This is also the case of a newly recorded dipinto painted in red on the north wall of the portico, in the scene depicting nurses of the child Hatshepsut (Fig. 1). ${ }^{6}$ It was written $0.82 \mathrm{~m}$ above the pavement, and the height of the hieratic signs is $c .1 .2 \mathrm{~cm}$. The text reads as follows (cf. Figs 2-3):

Transliteration:

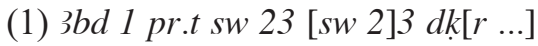

(2) $s w 20[+x$ ? $]$

Translation and commentary:

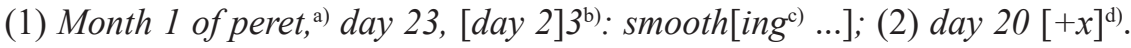

a) Only tiny traces of the group have been preserved.

b) There is no way to insert here: $h r w p n$, as would be expected. The reason for doubling the numeral remains rather obscure. On the other hand, it is highly doubtful to read here any numeral higher than the preceding one, though there is enough space for numerals 2 or 3 beside the preserved 3; even less justified seems to be the numeral 13. There is no way whatsoever to denote in this way the period of time needed to perform the work; for

\footnotetext{
${ }^{5}$ Naville 1897: 6; cf. Karkowski, Winnicki, Brecciani 1983: 93.

${ }^{6}$ Cf. Naville 1897: Pl. 55.
} 
this see, e.g. Megally 1977b: 40. As a consequence, the apparent repetition of the numeral looks rather like a simple dittography.

c) An older orthography of the verb seems to have been used here (its later form $d g$ 3 cannot be substantiated anyway). As for the writing and meaning of the verb $d k r / d g$ 3, cf. $W b \mathrm{~V}$, 499; Hayes 1942: 31, 41; Černý 1976: 207; Meyer 1982: 254 (note 6: 'Verputzen', 'Putzarbeiten'); Hannig 1995: 988f.; Lesko 2002-2004: 256 (vol. II). The older view on the subject, as presented by William Hayes and others, i.e. to translate the term simply as 'plastering', cannot be upheld in the light of available sources relating to the progress of work on temple decoration, cf. Iwaszczuk 2010: 43f. It must be remembered that the methods applied to smooth the wall surface were in fact twofold: dressing or polishing, and plastering the stone surface. In this particular case the inscription was written directly on the polished stone surface, which was the starting point for the carving of the restored figures. This particular circumstance implies the meaning adopted here. It is open to question whether the infinitive, which seems most plausible, or another form of the verb has been used here.

d) Perhaps a higher numeral than those in line 1 should be expected here, but nothing has been preserved of it; the numeral 20 remains rather doubtful - one would expect presumably a later date than the preceding one (thus relating perhaps to a later stage of restoration work).

The reason for interpreting the text as being left by ancient restorers lays in the mere fact that it was written on the restored figure of one of the divine nurses, and more exactly on the edge line of the figure in question. The missing part of the inscription had been originally written on the background which must have been extracted in the process of re-carving the figure, destroyed as the result of Amarna erasures. The palaeography of the text does not provide a decisive argument for its precise dating - this is mostly because of its concise character. The context does not leave any doubts, however, that it must be connected with post-Amarna restorations. Anyway, the cartouches of Ramesses II, written in some places on the walls of the portico, provide a more precise point of reference.

There is one more piece of evidence referring to the work conducted in this part of the temple. The question remains open as regards its precise dating. It is located at the opposite end of the Birth Portico, i.e. on its southern wall, just to the left of the decorated part (1.27-1.38m above the pavement). The inscription had been written in red ink (Figs 4-5) with unusually large hieratic signs (c. $4.5-6 \mathrm{~cm}$ in height):

Transliteration:

Ird[...] [blank space?] ssp(.w) 3bd 3 3ht sw 29 [blank space?] Mnw-nht(.w)

Translation and commentary:

Ired[...];;) [blank space?]; received: ${ }^{\text {b) }}$ month 3 of akhet, day 29; [blank space?]; Min-nakht ${ }^{\text {c) }}$.

a) In spite of lack of a determinative (A1 in Gardiner's sign-list) at the end, it is reasonable to read this as a personal name (not recorded, however, in Ranke 1935). An alternative 


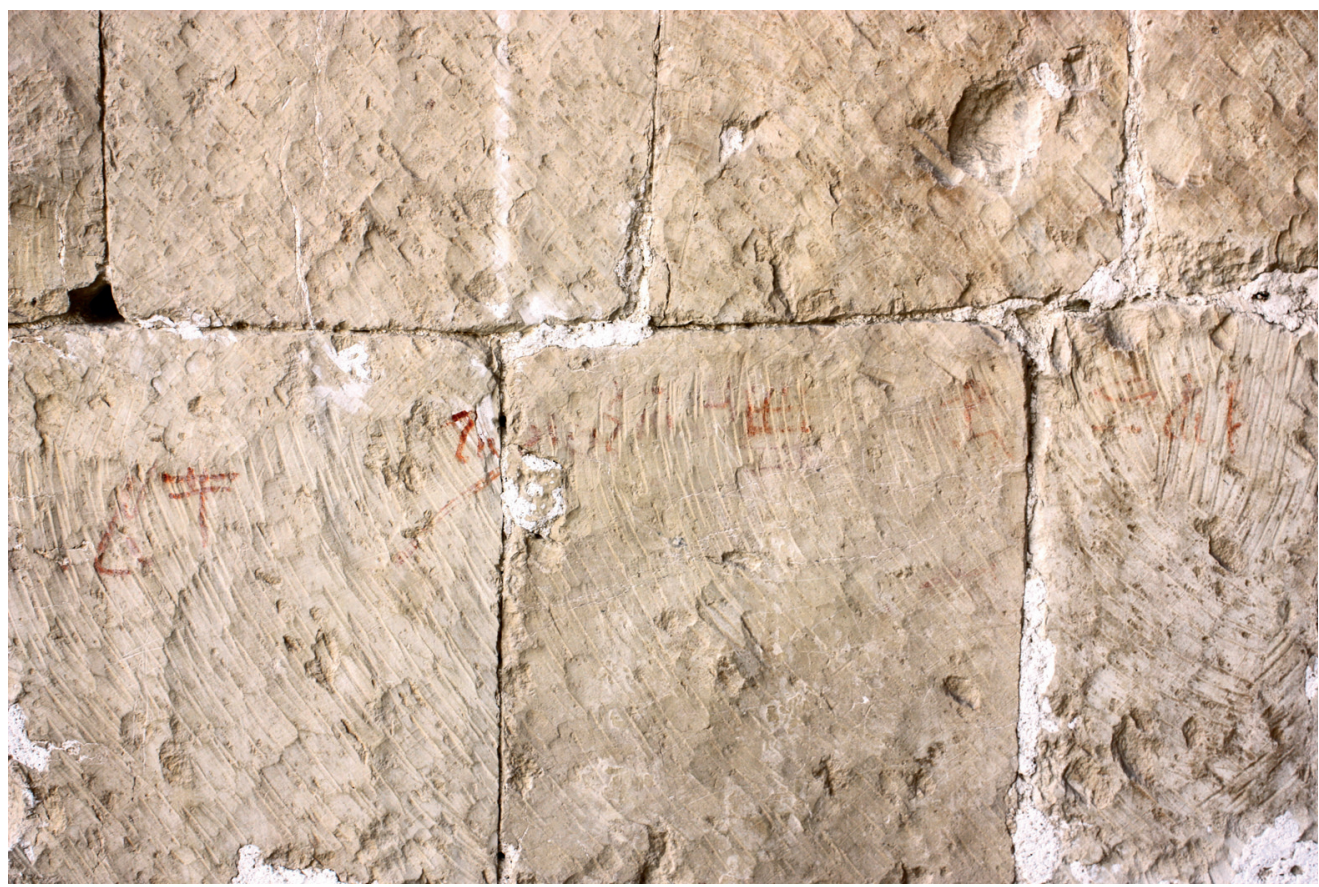

4. Inscription of Ired and Minnakht in the Birth Portico, southern wall (Phot. M. Barwik).
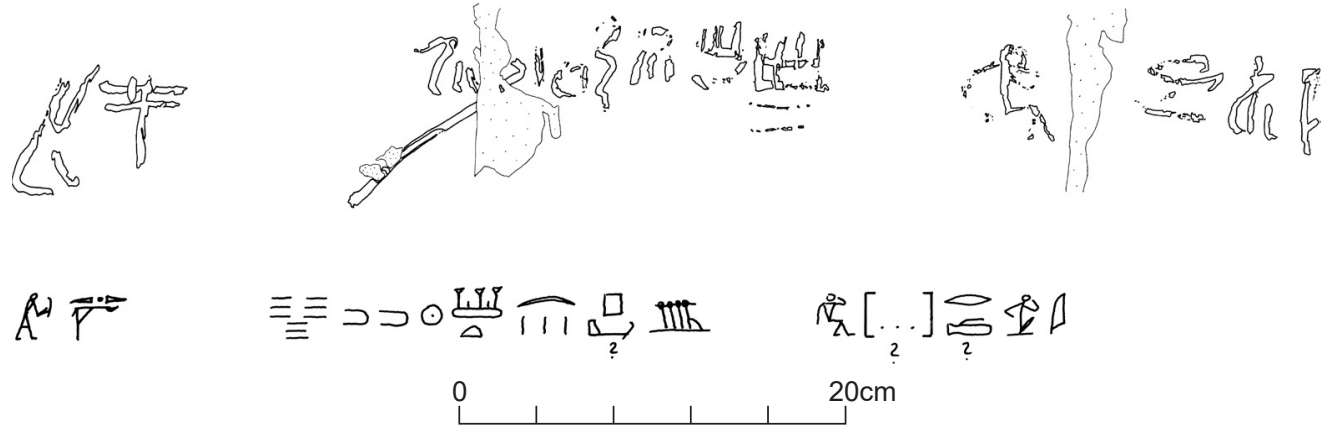

5. Inscription of Ired and Minnakht - facsimile and transcription of the text (Drawing: M. Barwik).

reading 'Irn[...] cannot be substantiated more precisely; for the reading proposed here, see the comment given below. The lacuna after group $r d$ poses a problem, as it falls exactly on the joint between two blocks of masonry. It is possible, however, that the scribe decided to write the last sign of the name just after the joint.

b) Two parallel lines below $s s p$ must be interpreted as purely accidental. As regards the palaeography of the sign šsp, see: Möller 1927: 33, no. 368 (vol. II); Megally 1971: Pl. L (1); compare also Wimmer 1995: 259 (vol. II) (forms of the early Nineteenth Dynasty have not been included). 


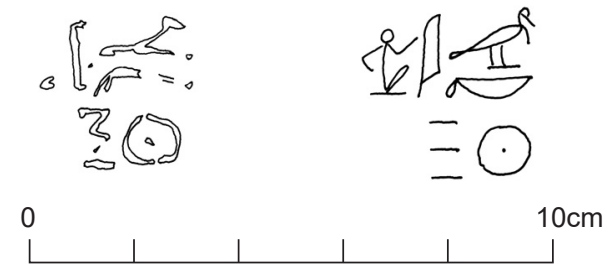

6. Dipinto of Baki on the northern wall of the second ramp of the temple - facsimile and transcription of the text (Drawing: M. Barwik).

For some remarks on orthography, and the administrative meaning of the term in the middle of the Eighteenth Dynasty, see also: Megally 1977a: 17f., 101, 207, 248f. It is hardly likely that the receiving of provisions or goods can be deduced here; for this, see: Megally 1977a: 247-249; Donker van Heel, Haring 2003: 120(f); cf. also: Grandet 2006: 94 (oIFAO 10080). More probably, however, the reason for writing the note in question on the temple wall was accepting the work done on this part of the wall (or else all portico

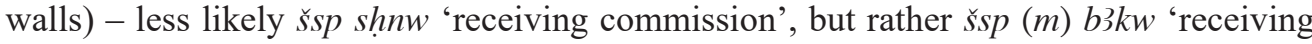
the work', which is a common technical term in administrative texts of the Ramesside period, cf. Janssen 1993: 88f.

c) It does not seem plausible that blank spaces left between three segments of the inscription should be interpreted simply as lacunae; thus one would assume that the name was written here without any title - as a consequence it seems reasonable to assume that the person in question was a simple workman. Here too the name is written without the determinative.

The dating of the dipinto poses some problems, as the palaeography does not help to resolve the question. The hieratic form of numeral 9, denoting the day of the month, points rather to the early period of the Eighteenth Dynasty. ${ }^{7}$ Significantly the name Ired (exactly in the form presented by the dipinto) appears among newly published Tuthmoside ostraca from Deir el-Bahari, relating to the building of a temple (oCairo DeB no. 435, 6) ${ }^{8}$ The person in question has been identified there as one of the stonecutters ( $h r t y(. w)-n t r)$ engaged in the temple building. Significantly enough the second person mentioned in the inscription has been recorded on another ostracon from the same lot - this is oCairo DeB no. 488 (line 3). ${ }^{9}$ Here again he is enumerated among stonecutters working in the temple area. Nothing certain can be said about Ired nor Minnakht except the mere fact that they participated in the work in the temple, ${ }^{10}$ presumably in the work of simply dressing the stone surface. Certainly their activity must be clearly distinguished from that of sculptors attested elsewhere in relation to the work of restoration of the temple decoration in

\footnotetext{
${ }^{7}$ Cf. Möller 1927: 60, no. 664 (vol. II); Megally 1971: Pls XXIX (f-i), XXXI (j). As regards its later form in the writing of the late Eighteenth Dynasty, cf. e.g. Condon 1984: Pls 4-5 (pap.Brooklyn 35.1453A, V/H, 17; $\mathrm{H} / \mathrm{V}, 9)$.

${ }^{8}$ Hassan 2015: 195, 221, Figs 13-14.

${ }_{9}$ Hassan 2015: 198-200, 222, Figs 15-16.

${ }^{10}$ Thus most probably the Temple of Hatshepsut should be taken into consideration; as regards the finding place of the ostraca, see a comment by Hassan 2015: 179: from the north-east court of the Hatshepsut temple or from one of Naville's dumps.
} 


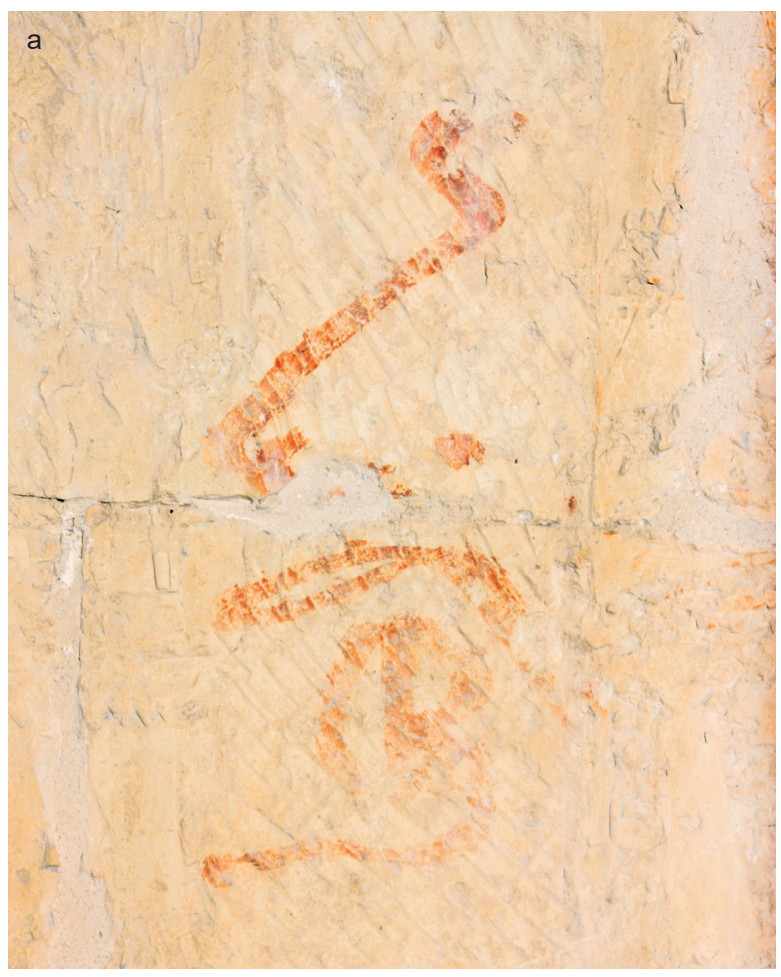

b

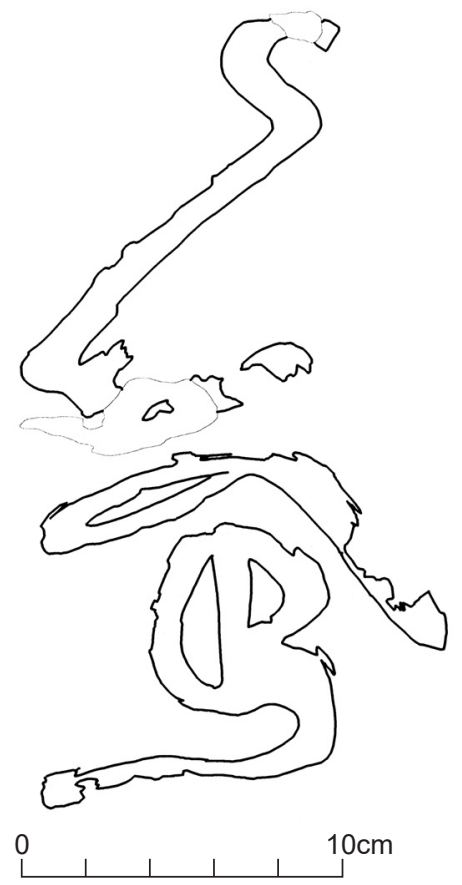

7. Inscription on the west wall of the portico: a. photograph; b. facsimile (Phot. M. Barwik; drawing: I. Prakapchuk).

the later period. ${ }^{11}$ It is very likely indeed that the inscription of the southern wall of the portico had been covered by whitewash (and then invisible?) after completing, receiving and subsequent recording of the work in question.

It seems that a similar purpose can be ascribed to a nearby tiny hieratic dipinto (written in red paint), giving only the name of a certain Baki, ${ }^{12}$ and a date: 'day 3' (Fig. 6). The dipinto has been written in fine Tuthmoside hieratic on the roughly smoothed northern wall of the ramp of the middle terrace of the temple (in its western part, $1.66 \mathrm{~m}$ above the stairs leading to the portico). Although Baki has not been recorded in the published sources relating to the building of the Temple of Hatshepsut, it is possible that he was another stonemason engaged in dressing the stone walls of the temple alongside Ired and Minnakht.

There is some additional inscriptional evidence that can be related perhaps to the period of restorations conducted in this part of the temple. This is a large hieratic dipinto (Fig. 7), which has been written on the erased hieroglyphic inscription just between the scene

\footnotetext{
11 Cf. Barwik 2013.

12 Cf. Ranke 1935: 90 (13).
} 
depicting intercourse of queen Ahmose with Amun, and that of Amun turning towards god Khnum. ${ }^{13}$ The text written in red paint is located $1.28 \mathrm{~m}$ above the pavement. Quite obviously this is not a personal name of the type Bak/Baki attested in the onomastic material of the period, ${ }^{14}$ because of the determinative, which rather looks like Möller's sign no. $32 .{ }^{15}$ The possibility exists, however, that the word in question relates to the figure of the pregnant queen Ahmose, depicted nearby, just a few metres to the right. In such a case the inscription, being presumably a sort of comment to the scene, ${ }^{16}$ should be read perhaps as $b k 3 / b k$ (det: Möller's sign no. 65 ), ${ }^{17}$ a form of the passive participle(?) of the verb meaning 'to be pregnant'. ${ }^{18}$

Unfortunately, we cannot now read the name of the scribe who left his signature beside an official restoration inscription of Ramesses II, located slightly to the right of the latter, near the figure of god Khnum (1.45m above pavement). Only tiny traces of the original inscription written in red have been preserved. Fortunately, the dipinto in question had been copied by Naville before it was damaged, and it can be partly read as: $s \breve{s} P 3-n f r-m-\underline{d} d$ $[\ldots] \cdot{ }^{19}$ It is hardly likely that such a scribe's signature has any relation to the inscription commemorating restoration undertaken in the pharaoh's name at the beginning of the Nineteenth Dynasty. More probably it can be dated to a much later period. As a matter of fact, the Twentieth Dynasty date of this signature may be inferred from the writing of the $n f r$-sign with a lotus flower. ${ }^{20}$ In such a case it may be taken as one more visitor's graffito left in the porticoes of the temple. ${ }^{21}$

\section{Acknowledgments}

I am grateful to Paul Barford for improving my English.

\section{References}

Barwik, M. 2013: Ancient restorers in the Hatshepsut temple at Deir el-Bahari in the light of newly found graffiti, EtudTrav XXVI/1, 96-101

Condon, V. 1984: Two Account Papyri of the Late Eighteenth Dynasty (Brooklyn 35.1453 $\mathrm{A}$ and $\mathrm{B}), \operatorname{RdE} 35,57-82$

${ }^{13}$ For the scenes in question, see Naville 1897: Pls 47-48; the dipinto, not recorded there, is located on the third column of inscription from the left (Naville 1897: Pl. 47 on the right margin).

${ }^{14}$ Cf. Ranke 1935: 90 (13), 92 (2).

15 Möller 1927: 3 (32) (vol. II).

${ }^{16}$ Unless it was not merely a kind of scribal exercise.

${ }^{17}$ Möller 1927: 5 (vol. II) - the Eighteenth Dynasty forms not recorded; compare however older forms recorded in: Möller 1927: 6 (vol. I).

${ }_{18} \mathrm{~Wb}$ I, 481; Lesko 2002-2004: 141 (vol. I). For the grammatical form, cf. Černý, Groll 1975: 474ff.

${ }^{19}$ Cf. Naville 1897: Pl. 48.

${ }^{20}$ Cf. a comment by Černý 1973: 201; Davies 1999: 101f.

${ }^{21}$ It is irrelevant here that $P 3-n f r-m-d d(. w)$ is the name of one of the sons of famous scribe of the royal necropolis Amennakht of the Twentieth Dynasty, and possibly another person of that name within the institution of the royal necropolis, cf. Davies 1999: 108f., 166. 
Černý, J. 1973: A Community of Workmen at Thebes in the Ramesside Period, BiEtud 50, Le Caire

Černý, J. 1976: Coptic Etymological Dictionary, Cambridge

Černý, J., Groll, S.I. 1975: A Late Egyptian Grammar, Rome

Ćwiek, A., Sankiewicz, M. 2008: The Scene of "Going round the Wall" on the North Wall of the Portico of the Birth, PAM XVIII, 290-294

Davies, B.G. 1999: Who's Who at Deir el-Medina. A Prosopographic Study of the Royal Workmen's Community, EgUit 13, Leiden

Donker van Heel, K., Haring, B.J.J. 2003: Writing in the Workmen's Village. Scribal Practice in Ramesside Deir el-Medina, EgUit 16, Leiden

Epigraphic Survey 2009: The Eighteenth Dynasty Temple, Part 1: The Inner Sanctuaries, with Translations of Texts, Commentary and Glossary, Medinet Habu IX, OIP 136, Chicago

Grandet, P. 2006: KY JNR ŠRJ, « un autre petit caillou ». Ostraca hiératiques documentaires inédits de l'IFAO, [in:] Dorn, A., Hofmann, T. (Eds), Living and Writing in Deir el-Medine. Socio-historical Embodiment of Deir el-Medine Texts, AegHelv 19, Basel, 93-105

Hannig, R. 1995: Die Sprache der Pharaonen: Großes Handwörterbuch Ägyptisch-Deutsch (2800-950 v. Chr.), KAW 64, Mainz a/Rhein

Hassan, Kh. 2015: Some 18th Dynasty Hieratic Ostraca from Deir el-Bahri, BIFAO 115, 179-229

Hayes, W.C. 1942: Ostraca and name Stones from the Tomb of Sen-mūt (No.71) at Thebes, New York

Iwaszczuk, J. 2010: The Works of Seninefer. A Contribution to the Question of the Decoration of the Temple of Queen Hatshepsut in Deir el-Bahari, EtudTrav XXIII, 39-46 Janssen, J.J. 1993: B3kw: From work to product, SAK 20, 81-94

Karkowski, J., Winnicki, J.K., Brecciani, E. 1983: Amenhotep, Son of Hapu and Imhotep at Deir el-Bahari - Some Reconsiderations, MDAIK 39, 93-105

Lesko, L.H. 2002-2004: A Dictionary of Late Egyptian I-II, Providence

Martinez, P. 2007: Restaurations post-amarniennes commanditées par Ramsès II : un cas d'école à Deir el-Bahari, Memnonia XVIII, 157-176

Megally, M. 1971: Considérations sur les variations et la transformation des formes hiératiques du papyrus E. 3226 du Louvre, BiEtud 49, Le Caire

Megally, M. 1977a: Recherches sur l'économie, l'administration et la comptabilité égyptiennes à la XVIII ${ }^{e}$ dynastie d'après le papyrus E. 3226 du Louvre, BiEtud 71, Le Caire

Megally, M. 1977b: Notions de comptabilité à propos du papyrus E. 3226 du Musée du Louvre, BiEtud 72, Le Caire

Meyer, Ch. 1982: Senenmut. Eine prosopographische Untersuchung, Hamburg

Möller, G. 1927: Hieratische Paläographie I-II, Leipzig

Naville, E. 1897: The Temple of Deir el Bahari II. The Ebony Shrine. Northern Half of the Middle Platform, MEEF 14, London 
Niwiński, A. 1985: Miscellanea de Deir el-Bahari, MDAIK 41, 197-227

Ranke, H. 1935: Die altägyptischen Personennamen I, Glückstadt

Strauß-Seeber, C. 2009: Tintennotizen in der Hathorkapelle Thutmosis' III, [in:] Kessler, D. et al. (Eds), Texte-Theben-Tonfragmente. Festschrift für Günter Burkard, $\ddot{A} A T$ 76, Wiesbaden, 399-405

Wimmer, S. 1995: Hieratische Paläographie der nicht-literarischen Ostraka der 19. und 20. Dynastie I-II, $\ddot{A} A T 28$, Wiesbaden 


\section{ÉTUDES et TRAVAUX XXXI / 2018}

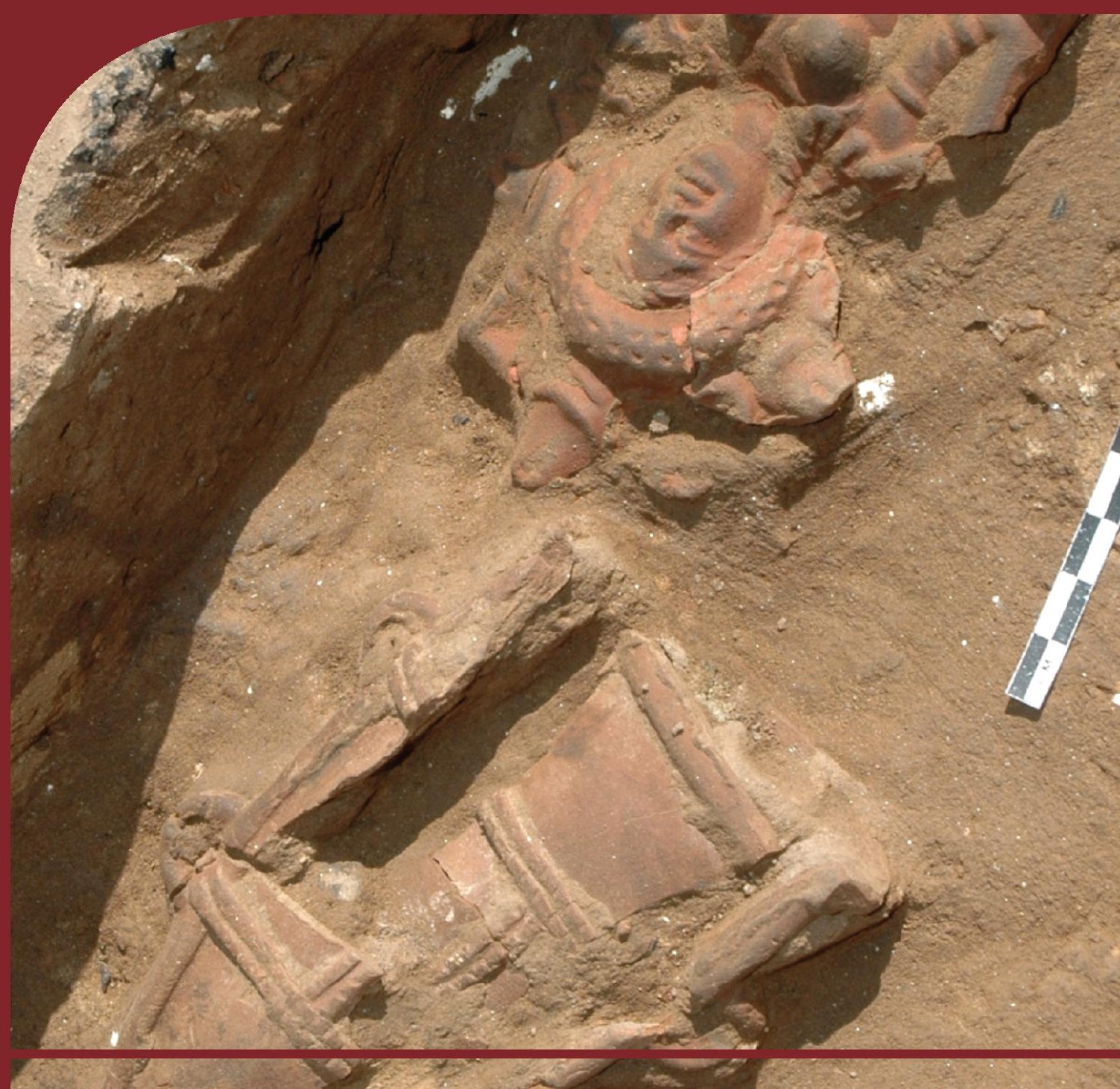

Institut des Cultures iyréditerranéennes et Oilentales FORIKSiO - de PAcadémie Polonaise des Sciences DS PA 


\section{COMITÉ DE RÉDACTION SCIENTIFIQUE}

Maciej Makowski - rédacteur en chef

Jadwiga Iwaszczuk - rédacteur

Mariusz Drzewiecki - sécretaire de la rédaction

Karol Myśliwiec - rédacteur thématique du volume

CONSEIL SCIENTIFIQUE DU JOURNAL

M. Kobusiewicz (IAE PAS, Warszawa), E. Laskowska-Kusztal (IMOC PAS, Warszawa)

D. Michaelides (University of Cyprus, Nicosia)

J.Ch. Moretti (IRAA-MOM, Université de Lyon 2/CNRS)

D. Raue (Ägyptisches Museum der Universität Leipzig), P. Reynolds (ICREA, España)

D. Welsby (British Museum, London)

\section{COMITÉ SCIENTIFIQUE DE LECTURE}

H.D. Baker (University of Toronto), P. Ballet (ArScAn-ESPRI, Université Paris Nanterre),

N. Beaux Grimal (IFAO, Cair/Collège de France, Paris), A. Dodson (University of Bristol),

L. Gabolde (CNRS), C. Gobeil (Egypt Exploration Society, London),

J. Holaubek (Institut für Ägyptologie, Wien), S. Ikram (American University in Cairo),

K. Innemée (Universiteit Leiden), Ch. Leitz (Universität Tübingen),

A. Loprieno-Gnirs (Universität Basel), Ch.E. Loeben (Museen für Kulturgeschichte, Hannover),

S. Ortisi (Universität München), A. Peignard-Giros (HiSoMA-MOM, Université de Lyon 2/CNRS),

E. Rova (Università Ca' Foscari Venezia), A. Sasson (San Diego Natural History Museum),

G. Schreiber (Eötvös Loránd University, Budapest), E. Teeter (University of Chicago),

Y. Tristant (Macquarie University, Sydney), V. Vaelske (independent researcher),

V.W.J. van Gerven Oei (independent researcher), H. Vymazalová (Charles University, Prague),

K. Winther-Jacobsen (Danish Institute at Athens),

J.A. Ostrowski, E. Papuci-Władyka, J. Śliwa (IA JU, Kraków),

R. Czerner (WUST, Wrocław), A. Ćwiek (IA AMU, Poznań),

K. Domżalski (IAE PAS, Warszawa), M. Pinker (FOS UW, Warszawa),

Ł. Niesiołowski-Spanò (IH UW, Warszawa), M. Gawlikowski (PCMA UW, Warszawa), K.O. Kuraszkiewicz (DE FOS UW, Warszawa), M. Barwik, P. Dyczek, W. Godlewski,

S. Rzepka, J. Żelazowski, A. Niwiński (IA UW, Warszawa)

\section{RÉDACTION TECHNIQUE}

Maciej Makowski, Jadwiga Iwaszczuk

CORRECTION LINGUISTIQUE

Jo Harper 
ÉTUDES et TRAVAUX

XXXI 
INSTYTUT KULTUR ŚRÓDZIEMNOMORSKICH I ORIENTALNYCH POLSKIEJ AKADEMII NAUK

\title{
STUDIA i PRACE
}

XXXI

\author{
gO IKŚiO \\ ESA PAN \\ WARSZAWA \\ 2018
}


INSTITUT DES CULTURES MÉDITERRANÉENNES ET ORIENTALES DE L'ACADÉMIE POLONAISE DES SCIENCES

\section{ÉTUDES et TRAVAUX}

XXXI

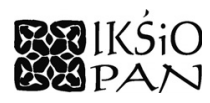

VARSOVIE

2018 
Publication scientifique financée dans le cadre du programme du Ministre de la Science et de l'Éducation Supérieure « Programme National de Développement de l'Humanistique » pour les années 2016-2021 (projet $n^{\circ} 3 \mathrm{bH} 15009983$ )

\title{
Harodowy PROGRAM ROZWOJU HUMANISTYKI
}

\author{
Copyright $($ ) \\ Instytut Kultur Śródziemnomorskich i Orientalnych PAN \\ et les Auteurs \\ Warszawa 2018
}

ISSN 2084-6762

(avant $2011: 0079-3566$ )

e-ISSN 2449-9579

Version première en papier, imprimée en Pologne - 150 copies

Version électronique accessible sur http://www.etudesettravaux.iksiopan.pl

Édition: Polskie Towarzystwo Historyczne et Wydawnictwo Neriton, Warszawa

Conception générale de couverture : J. Iwaszczuk Photo de couverture : P. Moser (C) Schweizerisches Institut für Ägyptische Bauforschung und Altertumskunde in Kairo

(terre cuites d'Aswan/Syene) 


\section{Table des matières}

KAROL MYŚLIWIEC

$(E T=E t u d T r a v / 50) \times 30$

HASSAN Aglan

Hatshepsut and the Apis Race: New Quartzite Relief Fragments

from Dra' Abu el-Naga

Amgad Joseph

Divine Wrath in Ancient Egypt

Amgad Joseph

Pain Infliction, Inflictors and Healers in Egyptian Religious, Magical

and Literary Perceptions

MirosŁaW BarwiK

New Dipinti in the Birth Portico of the Hatshepsut Temple at Deir el-Bahari

KrzyszTOF BorysŁaWsKi, ANNA NiwiŃSKA, ANDRZEJ NiwiŃSKI,

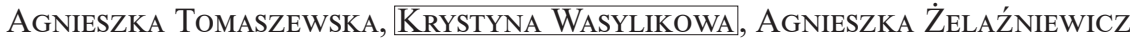

A Bulb of Narcissus on the Egyptian Mummy from University

of Wrocław Collection

LINDA CHAPON

Some Reliefs Representing the King in the Heb Sed Robe Discovered in the Henket-Ankh

Philippe Guillaume

Debunking the Latest Scenario on the Rise of the Pork Taboo

Mariola Hepa

A Clay Gladius Scabbard from Area 13c in the Ancient Roman Town of Syene

Emanuele E. Intagliata

Pinpointing Unrest at Palmyra in Early Islamic Period. The Evidence from Coin Hoards and Written Sources 
KATARZYNA KAPIEC

The Sacred Scents: Examining the Connection Between the ' $n t j w$ and $s f \underline{t}$ in the Context of the Early Eighteenth Dynasty Temples

DOMINIKA MAJCHRZAK

Remarks on the Iconographic Motif of the Birdman in Mesopotamian Glyptic Art of the Third Millennium BC

KAROLINA PAWLIK

Stone Artefacts from Late Roman Occupation Phases in Nea Paphos

ABRÉVIATIONS 
THE VOLUME IS PUBLISHED TO CELEBRATE

THE $50^{\text {TH }}$ ANNIVERSARY

OF THE

ÉTUDES ET TRAVAUX

ESTABLISHED IN 1966 